\title{
Effect of inhaled procaterol on cough receptor sensitivity to capsaicin in patients with asthma or chronic bronchitis and in normal subjects
}

\author{
Masaki Fujimura, Sayuri Sakamoto, Yumie Kamio, Takuma Bando, \\ Kazuyoshi Kurashima, Tamotsu Matsuda
}

\begin{abstract}
Background-To evaluate the effect of inhaled $\beta_{2}$ adrenergic agonists on the sensitivity of airway cough receptors, the effect of inhaled procaterol on cough induced by aerosolised capsaicin, a stimulant of $\mathbf{C}$ fibres, was studied in patients with asthma or chronic bronchitis and in normal subjects.

Method-Eleven patients with asthma and 10 with chronic bronchitis and 14 normal subjects participated. Increasing concentrations of capsaicin solution were inhaled for 15 seconds by tidal breathing through the mouth at one minute intervals until five or more coughs were elicited, before and 30 minutes after inhalation of $20 \mu \mathrm{g}$ procaterol or placebo (freon gas alone) through a metered dose inhaler. Cough threshold was defined as the lowest concentration of capsaicin that elicited five or more coughs. To evaluate the bronchodilator effect of procaterol and the bronchoconstrictor effect of inhaled capsaicin, forced expiratory volume in one second $\left(\mathrm{FEV}_{1}\right)$ was measured before and one minute after a capsaicin provocation test. This test was carried out both before and 30 minutes after treatment with procaterol or placebo.
\end{abstract}

Results-The geometric mean value of cough threshold to capsaicin was significantly increased by procaterol and placebo in both groups of patients but not in the control subjects. The increment in the cough threshold was not significantly different between the treatments with procaterol and placebo in each group. FEV $_{1}$ was significantly increased by procaterol but not by placebo in all three groups.

Conclusions-Inhaled procaterol has no effect on airway cough receptor sensitivity to capsaicin. The attenuation of the cough sensitivity seen after inhalation of procaterol in patients with asthma and bronchitis may result from tachyphylaxis to capsaicin.

(Thorax 1993;48:615-618)

Although $\beta_{2}$ adrenergic agonists have been used as antitussive drugs in Japan, contro- versy exists about whether they reduce the sensitivity of airway cough receptors. Cough induced by distilled water and prostaglandin $F_{2 a}$ is reduced by inhalation of fenoterol in both asthmatic and normal subjects, ${ }^{1-3}$ and cough induced by bronchoscopy is attenuated by inhaled fenoterol. ${ }^{4}$ Inhaled salbutamol, however, has no effect on cough induced by citric acid and capsaicin in normal subjects. ${ }^{23}$ We have shown that inhaled procaterol, a selective $\beta_{2}$ agonist, does not change cough receptor sensitivity to inhaled capsaicin and tartaric acid in normal subjects, ${ }^{5}$ indicating that inhaled $\beta_{2}$ agonists have no direct effect on cough receptor sensitivity in normal subjects. However, less is known about the effects of inhaled $\beta_{2}$ agonists on the sensitivity of cough receptors to capsaicin in patients with asthma and chronic bronchitis. Capsaicin, the active constituent of red pepper, stimulates cough receptors and may produce coughing by stimulating $\mathrm{C}$ fibre nerve endings. ${ }^{6-8}$ We examined the effect of inhaled $\beta_{2}$ agonists on the sensitivity of cough receptors to capsaicin in patients with either asthma or chronic bronchitis.

\section{Methods}

SUBJECTS

Eleven asthmatic patients (four men and seven women; mean age 57.6 years (range 38-70)), 10 patients with chronic bronchitis (six men and four women mean age 64.5 years (46-73)), and 14 normal women (mean age 20.3 years $(20-21)$ ) participated in the study. All subjects were non-smokers and none had suffered any viral infection for at least four weeks before the study. Informed consent was obtained from all subjects and the study was approved by the ethics committee of our university hospital.

Each patient with asthma satisfied the American Thoracic Society's definition of asthma. 9 One man and three women had extrinsic asthma with positive results in allergen skin tests or specific IgE antibodies to common aeroallergens, or both. Three men and four women had intrinsic asthma with no family history of allergy, no increased concentrations of specific IgE antibodies, and negative results in allergen skin tests. Chronic bronchitis was diagnosed according to the definition recommended by the American Thoracic Society. ${ }^{9}$ 
The study was carried out when symptoms were mild and stable, with patients taking only oral theophylline or oral and aerosol $\beta_{2}$ agonists with or without mucolytic agents. They had not received inhaled or oral steroids for at least eight weeks. All drug treatment was stopped at $9 \mathrm{pm}$ on the previous day to allow a washout time of at least 12 hours before measuring cough threshold to inhaled capsaicin between 9.30 and 12 noon on the test day.

\section{ASSESSMENT OF COUGH RECEPTOR}

SENSITIVITY TO INHALED CAPSAICIN

Capsaicin $(30.5 \mathrm{mg})$ was dissolved in Tween $80(1 \mathrm{ml})$ and ethanol $(1 \mathrm{ml})$ and then dissolved in physiological saline $(8 \mathrm{ml})$ to make a stock solution of $10 \mathrm{mmol} / \mathrm{l}$, which was stored at $-20^{\circ} \mathrm{C}$. This solution was diluted with physiological saline to make solutions starting at a concentration of $0.49 \mu \mathrm{mol} / 1$ and increasing by doubling concentrations up to $1 \mathrm{mmol} / \mathrm{l}$. Each subject inhaled a control solution of physiological saline followed by progressively increasing concentrations of the capsaicin solution. The nose was clipped and solutions were inhaled for 15 seconds every 60 seconds from a Bennett Twin nebuliser (Puritan-Bennett, Carlsbad, California) through the mouth during tidal breathing. Increasing concentrations were inhaled until five or more coughs were elicited. The nebuliser output was $0 \cdot 21 \mathrm{ml} / \mathrm{min}$. Cough threshold was defined as the lowest concentration of capsaicin that elicited five or more coughs.

\section{ASSESSMENT OF AIRWAY CALIBRE}

Forced expiratory volume in one second $\left(\mathrm{FEV}_{1}\right)$ was measured on a dry rolling seal spirometer (Transfer test, $\mathbf{P} \mathrm{K}$ Morgan, England) and was repeated at least three times on each of four occasions: before and one minute after control measurement of capsaicin cough threshold, before and $30 \mathrm{~min}$ utes after inhalation of $20 \mu \mathrm{g}$ procaterol or placebo.

\section{PROTOCOL}

Each subject attended on two days at the same time of day. After baseline measurement of the cough threshold and pulmonary function they received $20 \mu \mathrm{g}$ procaterol or placebo through a metered dose inhaler. The order of giving procaterol and placebo was randomised. Thirty minutes later cough threshold and pulmonary function were measured again. For each subject both experiments were completed within 14 days.

\section{DATA ANALYSIS}

Capsaicin cough thresholds are expressed as geometric means with the geometric standard error of the mean expressed as a factor. Values for $\mathrm{FEV}_{1}$ and forced vital capacity are reported as arithmetic means and standard errors of the mean (SE). Geometric mean values of cough threshold to capsaicin were compared before and after inhalation of procaterol or placebo and between these treatments by a paired $t$ test. In assessing

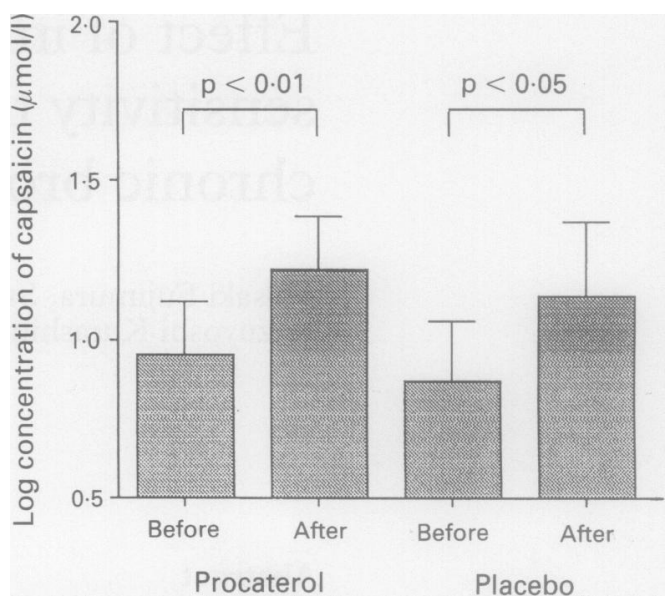

Figure 1 Effect of inhalation of procaterol or placebo on cough threshold to inhaled capsaicin in 11 patients with asthma (values are means and SE).

difference between changes in the cough threshold by procaterol and placebo the ratios of the cough threshold after these treatments to the baseline cough threshold were compared by a paired $t$ test. A p value of 0.05 or less was taken as significant.

\section{Results}

$\mathrm{FEV}_{1}$ and forced vital capacity before the first capsaicin challenge on the placebo day were $73 \%(7 \%)$ and $97 \%(5 \%)$ of predicted values in the asthmatic patients, $90 \%(5 \%)$ and $104 \%(4 \%)$ in the patients with chronic bronchitis, and $95 \%(3 \%)$ and $98 \%(4 \%)$ in the normal subjects.

Figure 1 shows the cough threshold to inhaled capsaicin before and after the inhalation of $20 \mu \mathrm{g}$ procaterol or placebo in the patients with asthma. Geometric mean values of cough threshold to inhaled capsaicin before the inhalation of procaterol and placebo were $8.85 \mu \mathrm{mol} / 1(1.48)$ and $7.33 \mu \mathrm{mol} / 1$ $(1.56)$, with no significant difference between them. The cough threshold was significantly increased by procaterol and placebo to $16 \cdot 6$ $\mu \mathrm{mol} / 1 \quad(1.48),(\mathrm{p}<0.01)$ and $13.3 \mu \mathrm{mol} / 1$ $(1.69),(\mathrm{p}<0.005)$, respectively.

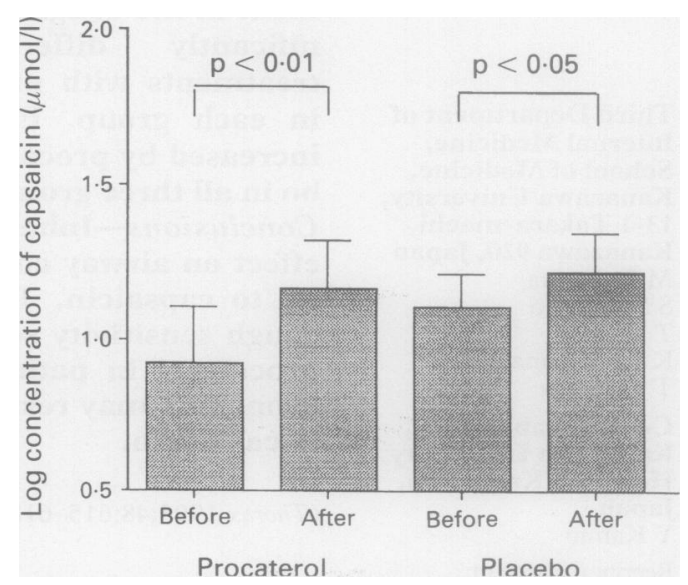

Figure 2 Effect of inhalation of procaterol or placebo on cough threshold to inhaled capsaicin in 10 patients with chronic bronchitis (values are means and SE). 
Figure 3 Effect of inhalation of procaterol or placebo on cough threshold to inhaled capsaicin in 14 normal subjects (values are means and $S E$ ).

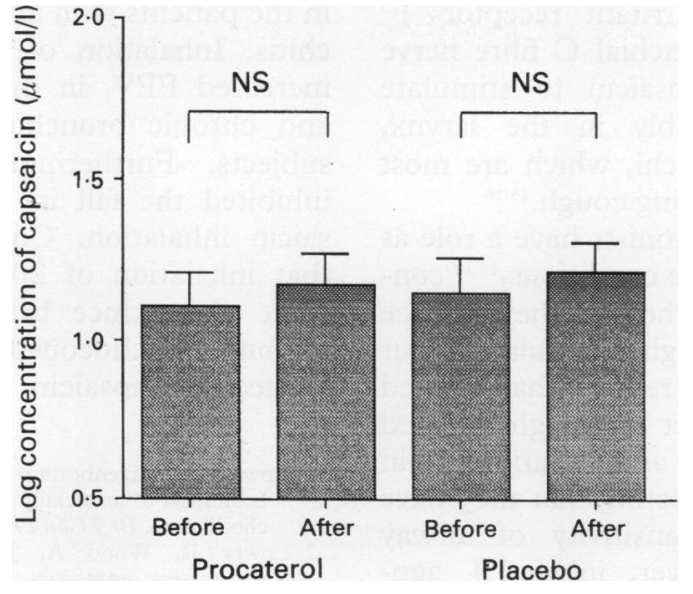

Figure 4 Mean (SE) increments in cough threshold to inhaled capsaicin with inhalation of procaterol and placebo in patients with asthma (BA) and chronic bronchitis $(C B)$ and in normal subjects (NC). Increment was defined as the ratio of the cough threshold after treatment to that before treatment. NS—not significant.

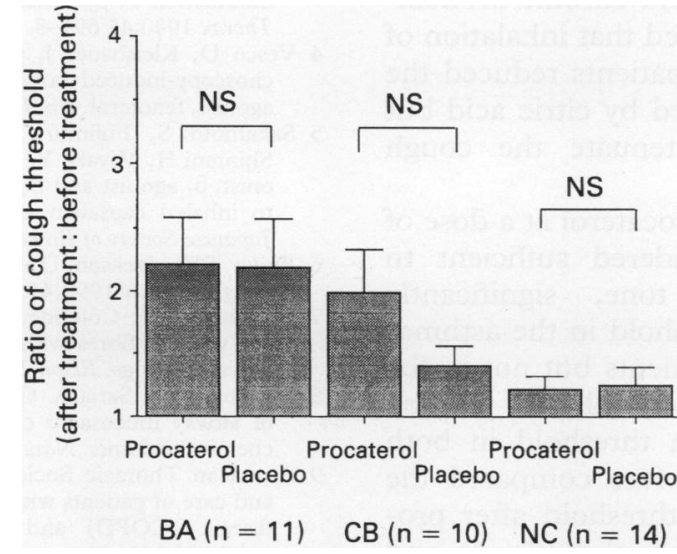

Figure 2 shows the capsaicin cough threshold before and after procaterol or placebo in the patients with chronic bronchitis. The geometric mean values before procaterol and placebo were $8.36 \mu \mathrm{mol} / 1 \quad(1.52)$ and 12.7 $\mu \mathrm{mol} / 1$ (1.29), and these values were not significantly different. The cough threshold was significantly increased by procaterol and placebo to $14.6 \mu \mathrm{mol} / 1(1.44)(\mathrm{p}<0.01)$ and $16.7 \mu \mathrm{mol} / 1$ (1.33) (p<0.05), respectively.

Figure 3 shows the capsaicin cough thresh- old before and after inhalation of procaterol or placebo in the normal subjects. The geometric mean value was $12.8 \mu \mathrm{mol} / 1(1 \cdot 26)$, $14.9 \mu \mathrm{mol} / 1$ (1.25), $14.1 \mu \mathrm{mol} / 1$ (1.27), and $16.4 \mu \mathrm{mol} / 1$ (1.24) before procaterol, after procaterol, before placebo, and after placebo, respectively. There was no significant difference between any pair of the four values.

Figure 4 shows the ratios of the cough threshold after inhalation of procaterol or placebo to the baseline cough threshold in the patients with asthma and with chronic bronchitis and in the normal subjects. The ratio was not significantly different between procaterol and placebo in each group.

Tables 1 and 2 show FEV $_{1}$ values before and 30 minutes after inhalation of procaterol or placebo. $F_{E V}$ was significantly increased by inhalation of procaterol in the three groups of subjects, but it was not changed by inhalation of placebo in any of the groups.

Tables 1 and 2 show the bronchoconstrictive effect of inhaled capsaicin at the cough threshold dose before and after inhalation of procaterol or placebo. Before both procaterol and placebo $\mathrm{FEV}_{1}$ was significantly decreased by capsaicin in the asthmatic and bronchitic patients but not in the normal subjects (tables 1 and 2). After procaterol inhalation the cough threshold dose of capsaicin did not significantly reduce the $\mathrm{FEV}_{1}$ in any of the three groups of subjects (table 1). After inhalation of placebo $\mathrm{FEV}_{1}$ was significantly decreased by capsaicin inhalation in the patients with chronic bronchitis but not in the asthmatic patients or the normal subjects (table 2 ).

\section{Discussion}

Cough usually results from the stimulation of sensory nerves in the airway. ${ }^{10}$ The larynx has two types of cough receptors: myelinated irregularly firing irritant receptors ${ }^{11}$ and non-myelinated $\mathrm{C}$ fibre nerve endings. ${ }^{12}$ The tracheobronchial tree also has two types of cough receptors: myelinated rapidly adapting

Table 1 Effect of cough threshold concentration of inhaled capsaicin on mean (SE) FEV in litres before and after inhalation of procaterol in three subject groups

\begin{tabular}{|c|c|c|c|c|c|c|}
\hline & \multicolumn{3}{|l|}{ Control } & \multicolumn{3}{|l|}{ After procaterol } \\
\hline & $\begin{array}{l}\text { Before } \\
\text { capsaicin }\end{array}$ & $\begin{array}{l}\text { After } \\
\text { capsaicin }\end{array}$ & $\begin{array}{l}\text { p value } \\
\text { between groups }\end{array}$ & $\begin{array}{l}\text { Before } \\
\text { capsaicin }\end{array}$ & $\begin{array}{l}\text { After } \\
\text { capsaicin }\end{array}$ & $\begin{array}{l}\text { p value } \\
\text { between groups }\end{array}$ \\
\hline \multicolumn{7}{|l|}{ Patients with: } \\
\hline Asthma $(n=11)$ & $1.69(0.12)$ & $1.60(0.13)$ & $<0.02$ & $2.01(0.12)^{\star}$ & $2 \cdot 00(0.13)$ & NS \\
\hline Chronic bronchitis $(n=10)$ & $2 \cdot 25(0.19)$ & $2 \cdot 21(0 \cdot 19)$ & $<0.05$ & $2.35(0.21) \dagger$ & $2 \cdot 37(0.21)$ & NS \\
\hline Normal subjects $(n=14)$ & $3.02(0.13)$ & $2.97(0.13)$ & NS & $3.07(0.14) \ddagger$ & $3.08(0.14)$ & NS \\
\hline
\end{tabular}

${ }^{\star} \mathrm{p}<0.002, \mathrm{fp}<0.02$, and $\neq \mathrm{p}<0.05$ compared with the control value before capsaicin challenge.

Table 2 Effect of cough threshold concentration of inhaled capsaicin on mean (SE) FEV, in litres before and after inhalation of placebo in three subject groups

\begin{tabular}{|c|c|c|c|c|c|c|}
\hline & \multicolumn{3}{|l|}{ Control } & \multicolumn{3}{|l|}{ After placebo } \\
\hline & $\begin{array}{l}\text { Before } \\
\text { capsaicin }\end{array}$ & $\begin{array}{l}\text { After } \\
\text { capsaicin }\end{array}$ & $\begin{array}{l}\text { p value } \\
\text { between groups }\end{array}$ & $\begin{array}{l}\text { Before } \\
\text { capsaicin }\end{array}$ & $\begin{array}{l}\text { After } \\
\text { capsaicin }\end{array}$ & $\begin{array}{l}\text { p value } \\
\text { between groups }\end{array}$ \\
\hline \multicolumn{7}{|l|}{ Patients with: } \\
\hline Asthma $(n=11)$ & $1.84(0.12)$ & $1 \cdot 77(0 \cdot 12)$ & $<0.05$ & $1.84(0 \cdot 12)$ & $1.80(0.12)$ & NS \\
\hline Chronic bronchitis $(n=10)$ & $2.24(0.22)$ & $2 \cdot 19(0.21)$ & $<0.05$ & $2.26(0.21)$ & $2.21(0.20)$ & $<0.05$ \\
\hline Normal subjects $(n=14)$ & $2.99(0.12)$ & $2.99(0.13)$ & NS & $3.01(0.13)$ & $2.96(0.12)$ & NS \\
\hline
\end{tabular}


stretch receptors (or "irritant receptors") ${ }^{13}$ and non-myelinated bronchial $\mathrm{C}$ fibre nerve endings. ${ }^{14}$ We used capsaicin to stimulate cough receptors, probably in the larynx, trachea, and major bronchi, which are most sensitive areas for provoking cough. ${ }^{15} 16$

Although inhaled $\beta_{2}$ agonists have a role as antitussive agents in some conditions, ${ }^{17}{ }^{18}$ controversy exists about whether they reduce sensitivity of airway cough receptors. ${ }^{1-5}$ Our study confirms previous reports that inhaled $\beta_{2}$ agonists have no effect on cough induced by citric acid, capsaicin, and tartaric acid in normal subjects, ${ }^{235}$ suggesting that they have no direct effects on sensitivity of airway cough receptors. However, inhaled $\beta_{2}$ agonists have not been shown to reduce cough receptor sensitivity to $C$ fibre nerve endings in patients with asthma and chronic bronchitis. Pounsford et al reported that inhalation of salbutamol in asthmatic patients reduced the number of coughs induced by citric acid but did not significantly attenuate the cough threshold. ${ }^{19}$

In our study inhaled procaterol at a dose of $20 \mu \mathrm{g}$, which was considered sufficient to reduce bronchomotor tone, significantly increased the cough threshold in the asthmatic and the bronchitic patients but not in the normal subjects. However, inhaled placebo also increased the cough threshold in both patient groups. We therefore compared the increment in the cough threshold after procaterol with that after placebo (fig 4) and there were no differences. Thus we conclude that inhaled procaterol has no effect on sensitivity of airway cough receptors to inhaled capsaicin in asthma and chronic bronchitis or in normal subjects.

The reproducibility of the dose-response curve for cough induced by capsaicin when challenges are performed at an interval of greater than 15 minutes is well established in normal subjects. ${ }^{20}$ We have confirmed these findings in our study, in which the challenges were performed 30 minutes apart. In contrast, in patients with asthma and with chronic bronchitis we have shown that the cough threshold is increased when capsaicin challenges are performed 30 minutes apart. As this change in cough threshold occurred when placebo was inhaled we believe that it is due to tachyphylaxis to the tussive effects of capsaicin.

We used the $\mathrm{FEV}_{1}$ to evaluate the bronchodilator effect of procaterol and the bronchoconstrictor effect of the cough threshold dose of capsaicin. Inhaled capsaicin significantly decreased $\mathrm{FEV}_{1}$ at this threshold dose in the patients with asthma and chronic bronchitis. Inhalation of procaterol significantly increased $\mathrm{FEV}_{1}$ in the patients with asthma and chronic bronchitis and in the normal subjects. Furthermore, inhaled procaterol inhibited the fall in $\mathrm{FEV}_{1}$ induced by capsaicin inhalation. Consequently, we believe that inhalation of $20 \mu \mathrm{g}$ procaterol is sufficient to produce bronchodilatation and to inhibit bronchoconstriction but not cough induced by capsaicin.

1 Lowry R, Higenbottam T, Johnson T, Godden D Inhibition of artificially induced cough in man by bronchodilators. Br $\mathcal{F}$ Clin Pharmacol 1987;24:503-10.

2 Lowry $R$, Wood A, Johnson $T$, Higenbottam $T$. Antitussive properties of inhaled bronchodilators on induced cough. Chest 1988;93:1186-9.

3 Nichol G, Nix A, Barnes PJ, Chung KF. Prostaglandin $F_{2 \alpha}$ enhancement of capsaicin induced cough in man modulation by $\beta_{2}$ adrenergic and anticholinergic drugs. Thorax 1990;45:694-8.

4 Vesco D, Kleisbauer J, Orehek J. Attenuation of bronchoscopy-induced cough by an inhaled $\beta_{2}$ adrenergic agonist, fenoterol. Am Rev Respir Dis 1988;138:805-6.

5 Sakamoto S, Fujimura $M$, Kurashima $K$, Yasui $M$ Shintani $\mathrm{H}$, Miyake $\mathrm{Y}$, et al. Effect of muscarinic antagonist, $\beta_{2}$ agonist and $\alpha_{2}$ agonist on the cough threshold to inhaled capsaicin and tartaric acid. Fournal of the fapanese Society of Bronchology 1991;13:229-34.

6 Fuller RW, Jackson DM. Physiology and treatment of cough. Thorax 1990;45:425-30.

7 Coleridge HM, Coleridge JCG. Impulse activity in afferent vagal C-fibres with endings in the intrapulmonary airways of dogs. Respir Physiol 1977;29:125-42.

8 Lundberg JM, Saria A. Capsaicin-induced desensitization of airway mucosa to cigarette smoke, mechanical and chemical irritants. Nature 1983;302:251-3.

9 American Thoracic Society. Standards for the diagnosis and care of patients with chronic obstructive pulmonary disease (COPD) and asthma. Am Rev Respir Dis 1987;136:225-44.

10 Karlsson JA, Sant'Ambrogio G, Widdicombe J. Afferent neural pathways in cough and reflex bronchoconstriction. F Appl Physiol 1988;65:1007-23.

11 Boushey HA, Richardson JG, Widdicombe JG, Wise JC. The response of laryngeal afferent fibres to mechanical and chemical stimuli. I Physiol (Lond) 1974;240: and chem $153-75$.

12 Boushey HA, Richardson PS, Widdicombe JG. Reflex effects of laryngeal irritation of the pattern of breathing and total lung resistance. $\mathcal{F}$ Physiol (Lond) 1972;224: 501-13.

13 Bartlett D Jr, Jeffery P, Sant'Ambrogio G, Wise JCM Location of stretch receptors in the trachea and bronchi of the dog. $\mathcal{F}$ Physiol (Lond) 1976;258:409-20.

14 Jammes Y, Fornaris E, Mei SS, Barrat E. Afferent and efferent components of the bronchial vagal branches in cats. F Auton Nerv Syst 1982;5:165-76.

15 Widdicombe JG. Receptors in the trachea and bronchi of the cat. $\mathcal{F}$ Physiol (Lond) 1954;123:71-104.

16 Sant'Amgrogio JM. Information arising from the tracheobronchial tree of mammals. Physiol Rev 1982;62 531-69.

17 McFadden ER Jr. Exertional dyspnea and cough as preludes to acute attacks of bronchial asthma. $N$ Engl $f$ Med 1975;292:555-9.

18 Corrao WM, Braman SS, Irwin RS. Chronic cough as the sole presenting manifestation of bronchial asthma. $N$ Engl f Med 1979;330:633-7.

19 Pounsford JC, Birch MJ, Saunders KB. Effect of bronchodilators on the cough response to inhaled citric acid in normal and asthmatic subjects. Thorax 1985;40: 662-7.

20 Collier JG, Fuller RW. Capsaicin inhalation in man and the effects of sodium cromoglycate. $\mathrm{Br} \mathcal{F}$ Pharmacol 1984;81:113-7. 